\title{
PRIORITAS PENGELOLAAN USAHA PENANGKAPAN IKAN KURAU DI PAMBANG PESISIR KABUPATEN BENGKALIS PROVINSI RIAU
}

\author{
Muhammad Natsir Kholis $^{1 *}$, Ronny I Wahju ${ }^{2,}$ Mustaruddin $^{2}$ \\ ${ }^{1}$ Staf Pengajar Program Studi Pemanfaatan Sumberdaya Perikanan \\ Universitas Muara Bungo-Jambi \\ ${ }^{2}$ Staf Pengajar Departemen Pemanfaatan Sumberdaya Perikanan, Institut Pertanian Bogor \\ "Email: kholis2336@gmail.com
}

\begin{abstract}
ABSTRAK
Penurunan produksi ikan kurau dari tahun ke tahun menimbulkan banyak permasalahan bagi nelayan Pambang Pesisir, terutama masalah konflik sosial yang sering terjadi beberapa tahun ini.Penelitian ini bertujuan untuk merumuskan Prioritas strategipengelolaan usaha penangkapan ikan kurau kedepan, agar terciptanya pengelolaan usaha penangkapan ikan kurau berkelanjutan.Pengumpulan data dilaksanakan pada bulan Juli sampai September 2016 di Pambang Pesisir Kabupaten Bengkalis Provinsi Riau dengan metode survei. Metode analisis yang digunakan yaitu analisis hirarki proses (AHP). Hasil analisis menunjukkan strategi pengelolaan usaha penangkapan ikan kurau lebih diarahkan ke strategi konservasi (KONSERV) sebagai prioritas pertama dengan nilai sebesar $(0,328)$, diikuti prioritas keduabantuan operasional (BOP) sebesar $(0,245)$, prioritas ketiga penyuluhan dan pembinaan (PDP) sebesar $(0,242)$ dan prioritas keempat kredit usaha rakyat (KUR) sebesar $(0,184)$ dengan inconsistency terpercaya 0,04 .
\end{abstract}

Kata Kunci: Ikan kurau, Analisis hirarki proses, Konservasi, Pambang Pesisir

\section{ABSTRACT}

The decrease of fish production from year to year has caused many problems for fishermen of Pambang Pesisir,especially the social conflicts that often occur over the years. This research is aimed to formulate management strategies priorityfor future kurau fish catching business, to create sustainable management of kurau fishing business.Data collection was conducted from July to September 2016 in Pambang Pesisir, Bengkalis District Riau Province by survey method.The analytical method used is process hierarchy analysis (AHP). The analysis result shows that management strategy of kurau fishing business is directed to conservation strategy (KONSERV) as first priority with value equal to $(0,328)$,followed by second priority of operational assistance (BOP) of $(0,245)$, third priority counseling and coaching (PDP) equal to $(0,242)$ and fourth priority of people's business credit (KUR) equal to 0,184 with trusted inconsistency 0,04 .

Keywords: Kurau Fish, Hierarchy analysis process (AHP), Conservation, Pambang Pesisir 


\section{PENDAHULUAN}

\section{Latar Belakang}

Konservasi sumberdaya pesisir dan lautan saat ini telah menjadi tuntutan dan kebutuhan yang harus dipenuhi sebagai harmonisasi kebutuhan ekonomi masyarakat dan lingkungan (sumberdaya alam) untuk dapat bersinergi agar tidak mengganggu keseimbangan baik lingkungan maupun pengelolanya.Hal itu mengingat berbagai permasalahan dan bentuk ancamanyang serius terhadap sektor perikanan terutama terkait dengan kelestarian sumberdaya hayati laut. Permasalahan utama dalam pengelolaan dan pengembangan konservasi perairan antara lain: adanya pemanfaatan berlebih (over exploitation) di beberapa wilayah terhadap sumber daya hayati pesisir dan laut, penggunaan teknik dan peralatan penangkapan ikan yang merusak lingkungan, perubahan dan degradasi fisik habitat, pencemaran, introduksi spesies asing, konversi kawasan lindung menjadi peruntukan pembangunan Iainnya dan perubahan iklim global serta bencana alam (Rengi dan Brown, 2013)

Salah satu komoditas unggulan perikanan di perairan laut Kabupaten Bengkalis adalah ikan kurau. Ikan kurau memiliki nilai ekonomis yang tinggi di pasaran sehingga menjadi sasaran tangkap utama bagi nelayan. Harga per kilogram ikan kurau ini yaitu Rp 90.000 namun bisa berfluktuasi tergantung musimnya.Ikan kurau ini menembus pasar ekspor yang merupakan faktor harga ikan kurau per kilogramnya mahal karena banyak pemintaan dari negara-negara tetangga dan merupakan faktor pendorong terhadap peningkatan jumlah nelayan dan unit penangkapan ikan kurau di desa Pambang Pesisir Kabupaten Bengkalis (Purnomo et al., 2013).

Ikan kurau merupakan ikan target utama buruan masyarakat nelayan Kabupaten Bengkalis. Ikan kurau ditangkap secara besar-besaran karena harga jual ikan ini yang tinggi dan memiliki nilai tambah selain dagingnya seperti lambung dan gelembung renang. Lambung dan gelembung renang ikan kurau yang dikeringkan memiliki harga jual cukup tinggi sekitar Rp1 000 000/kg, lambung dan gelembung renang ikan kurau dipercaya mampu mengobati berbagai penyakit seperti asma, jantung, usus buntu dan gangguan kehamilan.

Nama ikan kurau dapat berbeda-beda disetiap wilayah, di Inggris ikan kurau biasa disebut ikan senangin ataugiant treadfin (tassel fish) atauindian salmon. Di Indonesia ikan kurau dan ikan senangin merupakan dua jenis ikan yang berbeda species tetapi satu family (keluarga), pada umumnya kedua jenis ikan ini memiliki banyak kesamaan, yang membedakannya yaitu mulut (moncong) ikan kurau lebih panjang dari pada ikan senangin, selain itu perbedaan yang mencolok lainnya dapat dilihat dari corak warna, bola mata dan sisik. Ikan kurau juga mempunyai sebutan lain di beberapa daerah di Indonesia seperti: baling/kuro (Jawa), laceh (Madura), senangin (Sumsel), selangih (sumatera bagian timur) dan tikus-tikus (Ambon) (Nasution, 2009).Dari uraian diatas penelitian ini bertujuan untuk merumuskan strategi pengelolaan usaha penangkapan ikan kurau kedepan, agar terjadinya pengelolaan usaha penangkapan ikan kurau berkelanjutan. 


\section{METODE PENELITIAN}

\section{Waktu dan Tempat}

Pengumpulandata dilaksanakan pada bulan Juli sampai September 2016 terpusat pada desa Pambang

\section{Sumber dan Teknik Pengumpulan Data}

Jenis data yang dikumpulkan yaitu data primer dan data sekunder. Data primer terdiri dari: data persepsi stakeholder terkait pengelolaan usaha unit penangkapan ikan kurau, seperti: kriteria, pembatas pengelolaan dan opsi pengelolaan. Sedangkan data sekunder terdiri dari:times series produksi, time series jumlah alat tangkap, nelayan dan armada penangkapan, peraturan pengelolaan perikanan PEMDA Bengkalis, KKP dan FAO.

Data primer dikumpulkan melalui wawancara (kuesioner) dan pengamatan langsung ke lapangan. Teknikpengumpulan data terkait persepsi stakeholderdalam menentukan strategi pengelolaan
Pesisir (Teluk Pambang) dan beberapa desa lainnya di Kabupaten Bengkalis Provinsi Riau. Peta lokasi pengambilan data dapat dlihat pada (Gambar 1).

usaha penangkapan ikan kurau dilakukan dengan teknik wawancara terstruktur terhadap responden dengan metode purpose sampling. Selain itu juga melakukan pengamatan langsung dilapangan yang bertujuan untuk mengumpulkan data dokumentatif, fungsinya membantu melihat konsistensijawaban responden (Mustaruddin, 2011).Pengumpulan data sekunder yaitu dengan melihat laporan statistik, laporan kegiatan dan hasil studi yang relevan dari dinas, balai penelitian, UPTD dan perguruan tinggi.Pertimbangan dalam penentuan semua kriteria, subkriteria pembatas (limit factor) dan alternatif, dilakukan atas dasar pertimbangan responden dan pihak terkait yang berkepentingan (seluruh stakeholder).

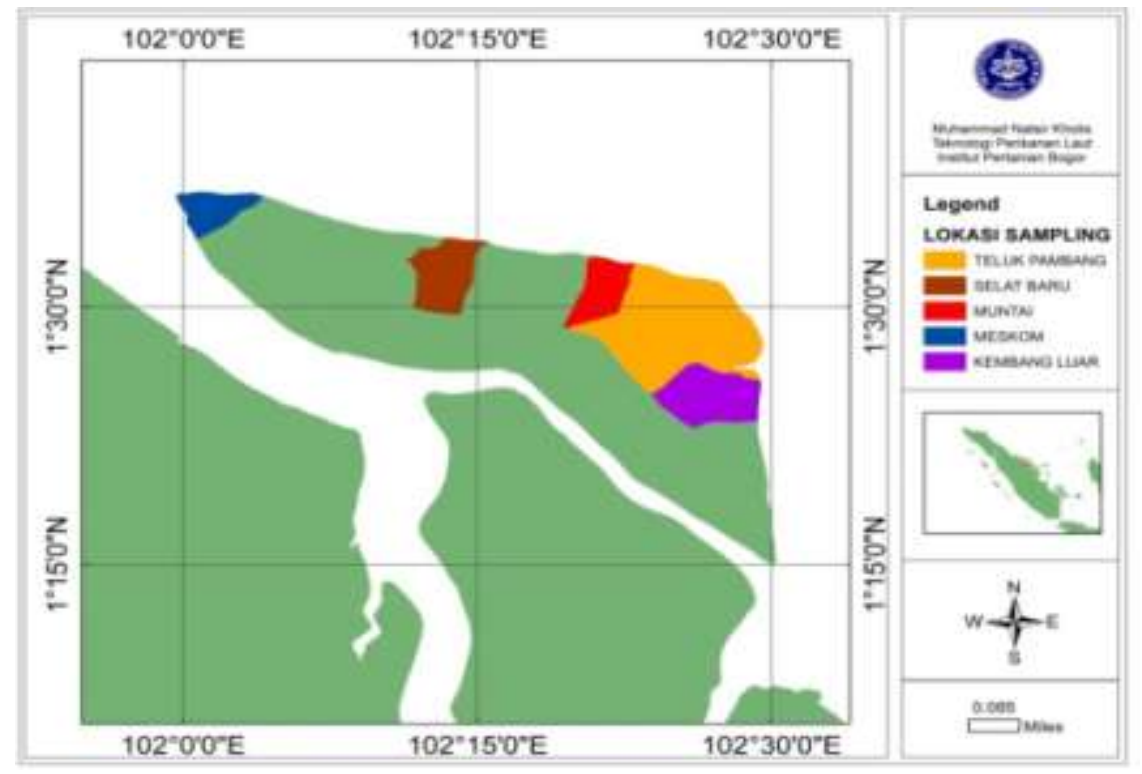

Gambar 1 Peta Lokasi Pengambilan Sampel 
Analisis Data

\section{Data}

diolah

menggunakananalytical

hierarchyprocess (AHP), analisis ini digunakan untuk merumuskan strategiprioritas pengelolaan usaha penangkapan ikan kurau kedepan.Pada prinsipnya, penentuan ini dilakukan dengan mempertimbangkan berbagai aspek kriteria yang ada dan beberapa hal yang menjadi faktor pembatasnya di perairan Pambang Pesisir.Terlepas dari itu, tahap awal yang perlu dilakukan dalam analisis hirarki ini adalah dekomposisi masalah. Dalam dekomposisi masalah ini akan menetapkan tujuan, kriteria, dan faktor pembatas untuk merumuskan opsi strategi pengelolaan usaha penangkapan ikan kurau di Pambang Pesisir. Selanjutnya setelah dekomposisi masalah dan menentukan beberapa komponennya

\section{HASIL DAN PEMBAHASAN}

\section{Kondisi Pengelolaan Usaha Penangkapan Ikan}

Kabupaten Bengkalis memiliki wilayah perairan yang paling luas diantara Kabupaten lainnya yang ada di Provinsi Riau. Letak Kabupaten Bengkalis berada dipesisir timur Pulau Sumatera, secara astronomis terletak diantara $2^{0} 7$ '37,2" sampai $0^{0} 55^{\prime} 33,6$ " lintang utara (LU) dan $100^{0} 57^{\prime} 57,6$ " sampai $102^{0} 30$ '25,2" bujur timur (BT) serta berbatas langsung dengan negara tetangga Malaysia (DKP Kab.Bengkalis, 2003).

Kondisi perikanan di

Pambang Pesisir pada umumnya merupakan usaha skala kecil dan merupakan nelayan turuntemurun.Unit teknologi penangkapan ikan kurau memiliki empat jenis alat barulah mengelompokkan dan menyusun kedalam bentuk struktur hirarki bertingkat.Pada tahap analisis skala banding berpasangan, data disiapkan dengan MS Excel, sedangkan penetapan skala banding berpasangan dan sistem pembobotannya mengacu kepada (Saaty, 1991) Data yang sudah lengkap selanjutnya dianalisis menggunakan sofware expert choice 9.5.

Untuk menguji kinerja hasil analisis, maka dilakukan uji konsistensi dan sensitivitas. Hasil uji konsistensi diharapkan menunjukkan Consistency Rasio(CR) di bawah 0,1. Bila CR bernilai lebih dari 0,1 berarti data yang digunakan tidak konsistensi dan harus dilakukan pengambilan ulang. Sedangkan untuk uji sensitivitas diharapkan hasil analisisnya tidak terlalu sensitif (Mustaruddin, 2011)

tangkap yang digunakan nelayan Pambang Pesisir, yaitu: jaring kurau, jaring tangsi, rawai dan pancing. Aspek teknis ini sering memicu konflik sosial di Pambang Pesisir akibat perebutan daerah penangkapan ikan dan minimnya pengetahuan teknologi dikalangan masyarakat nelayan, sehingga masih sulit untuk menerima teknologi kebaharuan

Selain itu nelayan Pambang Pesisir sangat kesulitan dalam memasarkan hasil tangkapannya karena belum adaya pelabuhan perikanan. Tidak hanya itu nelayan juga terikat modal melaut kepada toke atau pemilik kapal, hal inilah yang menyebabkannelayan Pambang Pesisir sangat sulit untuk berkembang.

Saat ini ikan kurau diisukan mengalami penurunan produksi yang 
tajam akibat penangkapan ikan kurau secara besar-besaran dan bahkan sampai terjadi konflik antar nelayan, sehingga perlunya pengelolaan yang baik agar terciptanya perikanan kurau yang berkelanjutan.Produksi ikan kurau Kecamatan Bantan dari tahun 2002 sampai 2007 sebesar 892.16 sampai $1.252,70 \mathrm{~kg}$ dengan upaya penangkapan (CPUE) tahunan ikan kurau di Bengkalis rata-rata tangkapan $2.355 .41 \quad \mathrm{~kg}$, effort 1.012,960 trip dan catch per unit effort(CPUE) 0,003. Potensi maksimum lestari $1.140,05$ dan upaya optimum sebesar 151.000 trip, sehingga telah melebihi batas upaya penangkapan (Syaifuddin, 2008).

Tingkat produksi ikan kurau di perairan Pambang Pesisir Kabupaten Bengkalis tahun 2012 sebesar 9.273 $\mathrm{kg}$, sementara Maximum Sustainable Yield (MSY) ikan kurau 4,067 kg. Dengan demikian telah terjadi kelebihan pemanfaatan sebesar 228 \% (Indra, 2013). Ikan kurau telah mengalami overfishing sebesar $33,42 \%$ dari tingkat pemanfaatan optimal upayanya sebesar 141,949/tahun, optimal biomass 15.321,34 ton dan optimal menangkap $4.407,72$ ton (Rengi et al., 2015).

Pengelolaan

perikanan merupakan suatu kegiatan yang kompleks, terstruktur dan berkesinambungan dalam satu sistem perikanan. Berdasarkan hal itu maka akan banyak timbul permasalahan yang terjadi, terutama konflik sosial dimasyarakat nelayan baik secara horizontal maupun vertikal. Semua itu disebabkan semakin terbatasnya sumberdaya ikan dan semakin sempitnya wilayah penangkapan.
Perairan Desa Pambang Pesisir merupakan salah satu wilayah potensial penangkapan ikan kurau di Kabupaten Bengkalis, sehingga tidak aneh jika daerah ini memiliki banyak permasalahan yang belum teratasi. Permasalahan yang terjadi saat ini yaitu: 1) sumberdaya ikan kurau mengalami penurunan produksi hasil tangkapan, 2) keuntungan nelayan menurun, 3) belum ada kejelasan aturan pemerintah dan kelembagaan ditingkat pelaku usaha serta 4) usaha penangkapan ikan kurau belum dikelola dengan baik.

Dari permasalahan ini ada beberapa hal yang perlu diperhatikan salah satunya teknologi yang digunakan dalam memanfaatkan ikan kurau itu sendiri, karena teknologi yang tidak ramah lingkungan akan merusak habitat dan berdampak terhadap populasi spesies ikan kurau. Untuk menuju Indonesia sebagai poros maritim dunia maka diperlukannya teknologi yang tepat untuk meningkatkan produktivitas, efisiensi, daya saing, ramah lingkungan dan keberlanjutan (sustainability) (Dahuri, 2016).Unit teknologi penangkapan ikan diharapkan dihitung finansialnya agar layak secara ekonomi skala kecil dan layak untuk dikembangkan secara berkelanjutan.Hal yang terpenting juga merumuskan strategi pengelolaan usaha penangkapan ikan kedepan dengan mempertimbangkan kriteria melalui pendekatan indikator pengelolaan berbasis Ecosystem Approach to Fisheries Management (EAFM) yaitu aspek biologi, teknis dan sosial-ekonomi (PKSPL-IPB 2011). 


\section{Pengelolaan Usaha Penangkapan Ikan Kurau}

Perbandingan Antar Kriteria dan

Subkriteria (Limit Factor)

Kriteria aspek yang

diperhatikan atau diprioritaskan

dalam pengelolaan usaha

penangkapan ikan kurau yaitu aspek

biologi, aspek teknis, aspek sosial

dan aspek ekonomi.Hasil analisis menunjukkan prioritas pada masingmasing kriteria diperoleh nilai biologi $(0,544)$, sosial $(0,158)$, ekonomi $(0,158)$ dan teknis $(0,140)$ dengan nilai inconsistency terpercaya 0.01.Hal ini menunjukkan bahwa kebijakan yang dipilih diutamakan dapat menjaga kondisi biologi ikan kurau karena kriteria aspek biologi memiliki nilai tertinggi. Perlu dipahami bahwa mempertahankan biologi ikan kurau yang berkelanjutan akan mendukung keseimbangan ekosistem di perairan Pambang Pesisir, dengan terjaganya biologi ikan kurau dari penangkapan yang berlebihan maka perekonomian nelayan pun ikut terjamin.

Kriteria aspek sosial dan kriteria aspek ekonomi memiliki nilai yang sama dan diprioritaskan kedua dalam penentuan prioritas strategi. Hal ini menunjukkan apabila mengelola usaha penangkapan ikan kurau berbasis biologi (ekosistem) maka perlu kita perhatikan aspek sosial dan ekonomi yang merupakan hal yang paling sensitif dalam kebijakan.Apalagi di daerah Pambang Pesisir merupakan daerah yang rawan konflik antar unit teknologi penangkapan ikan kurau karena perebutan daerah penangkapan. Sedangkan aspek teknis diprioritaskan ketiga dalam menentukan prioritas strategi, hal ini menunjukkan kepentingan aspek teknis untuk kondisi saat ini belum menjadi prioritas utama dalam pengelolaan usaha penangkapan ikan kurau, tetapi aspek teknis juga perlu pembaharuan dan pengembangan teknologi mengingat era globalisasi yang semakin canggih untuk peningkatan jumlah hasil tangkapan (Tahapary et al., 2010).

1) Aspek Biologi

Hasil analisis subkriteria aspek biologi menunjukkan Keterkaitan untuk pemenuhan kriteria aspek biologi potensi ikan mempunyai rasio kepentingan yang lebih tinggi dari pada yang lainnya dalam mendukung pemenuhan kriteria aspek biologi.POT-IKAN mempunyai rasio kepentingan tertinggi $(0,849)$ diikuti PASAR $(0,064)$, PERDA $(0,058)$ dan SDM $(0,030)$ dengan nilai inconsistensy terpercaya 0.01 .Hal ini dapat dipahami karena potensi ikan kurau yang melimpah lebih dapat mendukung keberlanjutan usaha penangkapan ikan kurau itu sendiri, dengan demikian kedepan sangat diharapkan pengelolaan usaha penangkapan ikan kurau lebih memperhatikan aspek biologi.

Potensi maksimum lestari (MSY) ikan kurau di Kabupaten Bengkalis sebesar 2.345,60 ton/tahun dengan jumlah tangkapan optimum/JTB sebesar 1876.48 ton/tahun, jadi ikan kurau masih cukup potensial untuk dikembangkan (Sari et al., 2009). kan kurau juga telah mengalami overfishing sebesar $33,42 \%$ dan lebih tangkap (carrying capacity) sebesar 28,820 ton/tahun (Rengi et al., 2015).

2) Aspek Teknis

Kriteria aspek teknis subkriteria pembatas (limit factor) PERDA mempunyai rasio kepentingan paling tinggi yaitu 
(0,370) diikuti SDM (0,340), PASAR $(0,177)$ dan POT-IKAN $(0,113)$ pada inconsistency terpercaya 0,01. Hal ini karena peraturan daerah lebih diutamakan sebagai pembatas penunjang aspek teknis untuk pengelolaan usaha penangkapan ikan kurau.Peraturan daerah sangat sentral berperan dalam berlangsungnya usaha penangkapan ikan. Apabila unit teknologi penangkapan ikan kurau tidak diatur, maka potensi ikan akan habis dan tidak ada keberlanjutan usaha.

Aspek teknis ini juga sering memicu konflik sosial di Pambang Pesisir akibat perebutan daerah penangkapan ikan dan minimnya pengetahuan teknologi dikalangan masyarakat nelayan, sehingga masih sulit untuk menerima teknologi kebaharuan. berdasarkan surat kepala stasiun pengawasan sumber daya kelautan dan perikanan (PSDKP) Belawan nomor: 03.19.03/Sta.2/SP.110/III/2014

tanggal 19 Maret 2014, alat tangkap jaring batu/jaring kurau adalah jenis alat penangkap ikan drift bottom gill net (jaring insang hanyut dasar) bukan trawl (pukat) sebagaimana yang dilaporkan sekelompok masyarakat di Kabupaten Bengkalis (PSDKP, 2014).

Hal ini mengingat Peraturan Menteri Kelautan dan Perikanan nomor: PER.18/MEN/2012 tentang Perubahan Ketiga PER.02/MEN/2011, bahwa alat penangkap ikan drift bottom gill net tidak termasuk sebagai alat penangkap ikan yang dilarang dioperasikan di wilayah pengelolaan perikanan Republik Indonesia (WPP RI). Konflik dengan nelayan tradisional terjadi karena pengoperasian alat penangkapan ikan jaring kurau tersebut dilakukan di
Jalur I (0 sampai 4 mil), sehingga menimbulkan konflik dengan nelayan lain seperti alat tangkap rawai (minilong line).

Akibat konflik sosial yang terus-menerus terjadi bahkan sampai terjadi pembunuhan dan pembakaran sejumlah unit teknologi penangkapan jaring batu/jaring kurau, maka keluarlah PERDA keputusan Bupati Bengkalis nomor 52 tahun 2003 tentang pelarangan pengoperasian jaring batu/jaring kurau (drift bottom gill net) di wilayah perairan 0 sampai 4 mil Kabupaten Bengkalis dan peraturan Gubernur Riau nomor 17 tahun 2006 tentang penghentian sementara alat tangkap jenis jaring batu/jaring kurau (drift bottom gill net) di wilayah perairan Tanjung Sekodi sampai dengan Tanjung Jati Kabupaten Bengkalis Provinsi Riau. Tetapi pada tahun 2011 kedua PERDA tersebut sudah tidak diberlakukan lagi karena bertentangan dengan PERMEN KP 02/MEN/2011 yang diperbaharui pada PERMEN KP 71/MEN/2017 tentang jalur penangkapan ikan dan penempatan alat penangkapan ikan di wilayah pengelolaan perikanan Republik Indonesia (WPP RI). Berdasarkan PERMEN KP tersebut jaring batu/jaring kurau di Kabupaten Bengkalis dikategorikan kedalam (gillnet oseanik) yaitu jaring insang yang memiliki ukuran mesh size $>4$ inch, panjang tali ris $<2.500 \mathrm{~m}$ per set dan maksimal menggunakan 4 (empat) set yang masing-masing set dilengkapi dengan 1 (satu) radio buoy, menggunakan kapal motor berukuran >30 GT, dan dioperasikan pada jalur penangkapan ikan III di WPP RI 571.

3) Aspek Sosial

Kriteria aspek sosial subkriteria pembatas (limit factor) POT-IKAN 
mempunyai rasio kepentingan paling tinggi yaitu $(0,331)$ diikuti SDM $(0,241)$, PASAR $(0,241)$ dan PERDA $(0,188) \quad$ pada inconsistency terpercaya 0,06. Hal ini karena potensi ikan lebih diutamakan sebagai pembatas penunjang aspek sosial untuk pengelolaan usaha penangkapan ikan kurau.potensi ikan sangat penting dalam menunjang aspek sosial dalam berlangsungnya pengelolaan usaha penangkapan ikan kurau berkelanjutan. Pengelolaan perikanan berbasis masyarakat/CBM (community based management) sangat diunggulkan saat ini, karena telah disepakati bersama sebelumnya ketentuan-ketentuan dalam operasi penangkapan (Satria, 2015). Dengan hal itu sumberdaya perikanan kurau lebih terjaga kelestariannya, karena masyarakat telah paham bagaimana mengelola sumberdaya laut dengan bijaksana. Dengan sumberdaya ikan kurau yang melimpah maka ekonomi masyarakat nelayan juga stabil dan tercukupi.

Sumberdaya manusia merupakan variabel penting yang menentukan status pemanfaatan dan potensi sumberdaya perikanan karena manusia berperan sebagai pengelola sumberdaya ikan yang hakekatnya pengelolaan terhadap manusia yang memanfaatkan sumberdaya ikan tersebut (Isnaniah, 2009).Upaya pengelolaan perikanan harus berbasis sumberdaya ikan baik demersal, pelagis, ikan karang, crustacea dan molusca, agar kelestarian sumberdaya ikan beserta lingkungan dapat terjaga.Masyarakat harus diikut sertakan dalam pengelolaan, baik secara langsung ataupun tidak langsung melalui program pendidikan dan pelatihan dalam konsep keanekaragaman hayati pesisir dan laut (Dahuri, 2003).

Salah satu usaha dalam pengelolaan sumberdaya secara lestasi ditempuh dengan pengelolaan sumberdaya perikanan berbasis komunitas.Pengelolaan sumberdaya perikanan berbasis komunitas ini, yang dimaksud yaitu segenap komponen yang terlibat baik secara langsung maupun tidak langsung dalam pemanfaatan dan pengeloaan sumberdaya pesisir dan lautan, diantaranya adalah masyarakat lokal, LSM, swasta, perguruan tinggi dan kalangan peneliti lainnya (Kusnandar dan Mulyani, 2015).

Pemberdayaan masyarakat dalam pengelolaan kawasan berbasis konservasi adalah wajib hukumnya untuk diikutsertakan.Pengelolaan perikananan yang mengedepankan peran masyarakat bagi peningkatan kesejahteraan adalah hal yang sangat penting untuk keberlanjutan usaha penangkapan ikan itu sendiri (Suraji, 2015).

4) Aspek Ekonomi

Kriteria aspek ekonomi subkriteria pembatas (limit factor) PASAR mempunyai rasio kepentingan paling tinggi yaitu $(0,365)$ diikuti POT-IKAN $(0,260)$, PERDA $(0,237)$ dan SDM $(0,188)$ pada inconsistency terpercaya 0,08 . Hal ini karena pasar dalam negeri dan luar negeri lebih diutamakan sebagai pembatas penunjang aspek ekonomi untuk pengelolaan usaha penangkapan ikan kurau.Pasar sangat penting dalam menunjang aspek ekonomi dalam berlangsungnya pengelolaan usaha penangkapan ikan kurau berkelanjutan. Dengan banyaknya target pasar baik di dalam maupun luar negeri, maka ekonomi nelayan Pambang Pesisir lebih stabil dan tercukupi. Ada empat akses 
dalam pemberdayaan masyarakat pesisir yaitu: akses terhadap SDA, akses terhadap partisipasi, akses terhadap pasar dan akses terhadap informasi dan pengetahuan. Akses terhadap pasar mempunyai arti bahwa nelayan mampu menjual hasil tangkapannya sendiri dan mengetahui informasi dinamika pasar yang berkembang, seperti harga komoditas di daerah lain (Dahuri, 2003). Pengendalian sumberdaya perikanan dapat dilakukan dengan cara pengendalian ekonomi, yaitu dengan menggunakan

\section{Prioritas Pengelolaan Usaha Penangkapan Ikan Kurau}

Perikanan kurau merupakan suatu sistem yang terdiri dari beberapa komponen atas elemen atau subsistem yang saling berkaitan dan memengaruhi satu sama lainnya, hal ini biasa disebut dengan bisnis perikanan. Maka dari itu usaha penangkapan ikan kurau perlu membuat suatu sistem pengelolaan yang terstruktur dalam jangka menengah untuk meningkatkan kembali hasil produksi agar terjadinya perikanan kurau yang berkelanjutan. Selain itu konflik sosial masih sering terjadi di Desa Pambang Pesisir Kabupaten Bengkalis, beberapa penyebab konflik disana yaitu perebutan daerah penangkapan (fishing ground), kecemburuan sosial/strata kelas nelayan, sistem bagi hasil (perekonomian), introduksi teknologi baru dan lainnya. Oleh karena itu, saat ini perikanan kurau perlu memprioritaskan strategi pengelolaan yang tepat terkait kondisinya saat ini. Fakta empiris menunjukkan bahwa konflik sosial merupakan bagian dari kehidupan dalam variabel ekonomi sebagai instrument pengendalian upaya penangkapan. Kegiatan penangkapan ikan sebagai suatu usaha atau kegiatan ekonomi dapat diberi insentif untuk tumbuh atau sebaliknya disinsentif untuk tidak tumbuh dengan cara manipulasi atau mengubah salah satu variabel ekonomi yang berpengaruh pada eksistensi dan keberlangsungan kegiatan ekonomi tersebut. Variabel ekonomi yang dipergunakan terdiri dari harga ikan, harga faktor input, subsidi, pajak dan biaya untuk memperoleh izin.

interaksinya satu dengan yang lain. Konflik dapat dijumpai pada setiap sistem sosial dari yang terkecil, seperti: antar individu, antar kelompok bahkan sampai yang terbesar antar bangsa (Kinseng, 2014).

Pengelolaan perikanan mencakup aspek penataan pemanfaatan sumberdaya ikan, pengelolaan lingkungan, serta pengelolaan kegiatan manusia, sehingga dapat dikatakan bahwa pengelolaan perikanan adalah manajemen kegiatan manusia dalam memanfaatkan sumberdaya ikan (Dahuri, 2003). Pentingnya pengelolaan sumberdaya perikanan karena beberapa persoalan (isu-isu), yaitu : masyarakat dapat memanfaatkan sumberdaya ikan secara bebas, berkaitan dengan pandangan open access laut, peningkatan eksploitasi karena meningkatnya jumlah peserta dan kemajuan teknologi yang dapat menimbulkan konsekuensi negatif dimasa mendatang, hasil tangkapan menurun akibat kegiatan penangkapan yang berlebihan, konflik antar nelayan dan antara sektor perikanan tangkap dengan 
kegiatan lain akibat hasil tangkapan (keuntungan ekonomis) yang sudah mulai menurun (FAO, 1997).

Maka dari itu usaha penangkapan ikan kurau perlu membuat suatu sistem pengelolaan yang terstruktur dalam jangka menengah untuk meningkatkan kembali hasil produksi agar terciptanya perikanan kurau yang berkelanjutan.Oleh karena itu saat ini perikanan kurau perlu merumuskan strategi pengelolaan yang tepat terkait kondisinya saat ini. Ada beberapa alternatif kebijakan pengelolaan perikanan kurau berkelanjutan berdasarkan wawancara terstruktur terhadap responden yaitu:

1) Konservasi (KONSERV) meliputi: PJAT (pembatasan jumlah alat tangkap), PUTPU (penggunaan unit teknologi penangkapan unggulan), RM (rehabilitas mangrove), PM (penutupan musim), UILT (ukuran ikan layak tangkap) dan PZPI (pembagian zona penangkapan ikan)

2) Bantuan Operasional (BOP) seperti: sarana dan prasarana, pengadaan bahan dan alat penangkapan ikan, pemukiman nelayan dan asuransi)

3) Penyuluhan dan Pembinaan (PDP) kelompok nelayan

4) Kredit Usaha Rakyat (KUR), koperasi nelayan dan pinjaman bank khusus nelayan.

Hasil analisis (Gambar 2) menunjukkan bahwa prioritas strategi pengelolaan usaha penangkapan ikan kurau lebih diarahkan ke strategi KONSERV sebesar $(0,328)$, diikuti BOP $(0,245)$, PDP $(0 ., 242)$ dan KUR $(0,184)$ dengan inconsistency terpercaya 0,04 . Dengan demikian implemenatsi kedepan diharapkan lebih menekankan pengelolaan usaha penangkapan ikan kurau berbasis konservasi yang mengarah ke pembatasan jumlah alat tangkap, penggunaan unit teknologi penangkapan unggulan, penutupan musim, rehabilitasi mangrove, pembagian zona penangkapaan dan ukuran ikan layak tangkap.Pengelolaan usaha penangkapan ikan kurau di Pambang Pesisir perlu pengelolaan yang tepat guna, mengingat data produksi ikan kurau mengalami penurunan dari tahun ke tahun. Strategi KONSERV menjadi solusi yang tepat dan sangat mendukung dalam keberlanjutan usaha penangkapan ikan kurau itu sendiri jika terealisasikan. Keberlanjutan usaha penangkapan ikan yang dilakukan secara tradisional maupun secara modern sangat dipengaruhi oleh banyak faktor. Usaha penangkapan ikan itu sendiri sangat sulit untuk diprediksi keberhasilannya, karena begitu peka terhadap faktor eksternal (musim dan iklim) serta faktor internal (teknologi, sarana dan prasarana serta modal). Kerentanan dalam proses produksi akan mengakibatkan adanya fluktuasi dalam perolehan hasil tangkapannya (Nomura and Yamazaki, 1975). 


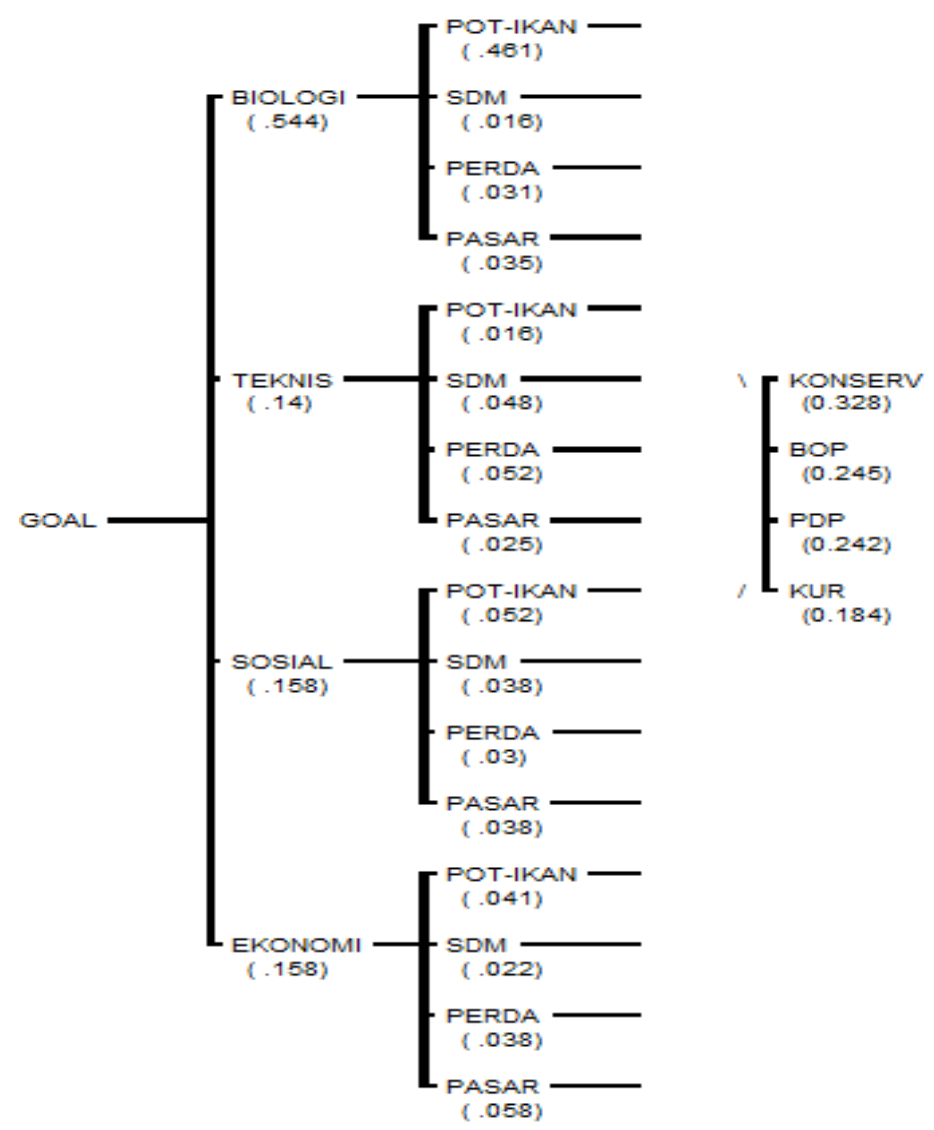

Gambar 2Prioritas Strategi Pengelolaan Usaha Penangkapan Ikan Kurau

Pengelolaan sumberdaya
kelautan dan perikanan yang
berkelanjutan tidak akan pernah
terlepas dari fungsi konservasi,
bahkan konservasi telah diyakini
sebagai upaya penting yang mampu
menyelamatkan potensi sumberdaya
tetap tersedia dalam mewujudkan
perikehidupan lestari yang
menyejahterakan. Pengelolaan
berbasis konservasi sangat sejalan
dengan prinsip-prinsip pembangunan
berkelanjutan, sehingga mampu
memberikan jaminan dalam efisiensi
pemanfaatan sumberdaya alam
sebagai sumber yang efektif
menyokong pemanfaatan lain secara
ramah lingkungan serta dapat
menumbuhkan keuntungan ekonomi
bagi masyarakat lokal (Suraji, 2015).
Tidak hanya ikan kurau di
Kabupaten Bengkalis yang perlu
dikonservasi, tetapi wilayah lainnya

di Provinsi Riau seperti Kabupaten Kepulauan Meranti juga sudah perlu dilakukan konservasi, hal ini didasari dengan adanya gejala over fishing, sulitnya menemukan ikan kurau di pasar lokal dan semakin banyaknya nelayan yang mencari ikan kurau sehingga sering terjadi konflik sosial. Konservasi ikan kurau dapat dilakukan dengan konservasi ekosistem, konservasi jenis ikan dan konservasi genetik ikan kurau. Dalam penentuan calon kawasan konservasi perairan dilakukan beberapa tahapan, dimulai dengan inventarisasi kawasan perairan, invetarisasi daerah penangkapan (fishing ground) dan daerah pemijahan dan asuhan (spawning dan nursery ground). Dengan kompleksitas permasalahan ikan kurau, maka diperlukan model teknologi konservasi yang memiliki 
potensi pengembangan dengan memperhatikan konsep pengelolaan ikan kurau sebagai integrasi ekosistem.Secara umum terdapat tiga strategi konservasi ikan kurau, yaitu strategi penguatan kelembagaan, strategi penguatan pengelolaan sumbedaya kawasan, strategi penguatan sosial, ekonomi, dan budaya (Rengi dan Brown, 2013).

Tingginya

dinamika

sumberdaya ikan itu tidak terlepas dari kompleksitas ekosistem tropis (tropical ecosystem complexities) yang telah menjadi salah satu ciri dari ekosistem tropis.Dalam konteks ini, pengelolaan perikanan yang tujuan akhirnya adalah memberikan manfaat sosial ekonomi yang optimal bagi masyarakat tidak dapat dilepaskan dari dinamika ekosistem yang menjadi media hidup bagi sumberdaya ikan itu sendiri (Adrianto, 2015).

Sumberdaya perikanan yang bersifat common property (kepemilikan bersama) memungkinkan terjadinya

Arahan Implementasi Prioritas Pengelolaan Usaha Penangkapan Ikan Kurau

Implementasi arahan yang tepat untuk pengelolaan usaha penangkapan ikan kurau berbasis konservasi (KONSERV) sebagai strategi proritas maka perlu diuji sensitivitasnya. Hasil uji sensitivitas ini dapat memberikan informasi keunggulan dari strategi prioritas tersebut, sekaligus harapan sebagai antisipasi perubahan-perubahan yang ada, sehingga implementasinya ke depan bisa berhasil maksimal. pemanfaatan secara berlebih sehingga menimbulkan inefisiensi dalam penggunaan input, return yang rendah, dan overfishing (tangkap lebih).Perikanan tangkap merupakan suatu sistem yang terdiri dari beberapa komponen atas elemen atau subsistem yang saling berkaitan dan memengaruhi satu sama lainnya yang disebut dengan bisnis perikanan (Zulbainarni, 2012).

Komponen-komponen perikanan tangkap terdiri dari: sarana produksi, usaha penangkapan, prasarana pelabuhan, unit pengolahan, unit pemasaran dan unit pembinaan (Kasteven, 1973).Oleh karena itu konservasi merupakan kunci dari pengelolaan usaha penangkapan ikan yang berkelanjutan saat ini, yang mana pengelolaan berbasis konservasi mampu mengukuhkan pilar keberlanjutan itu sendiri, mengukuhkan kedaulatan bangsa dan mengukuhkan kesejateraan masyarakat (Suraji, 2015).

\begin{tabular}{lrr}
\multicolumn{1}{c}{ Hasil } & analisis & sensitivitas \\
strategi & pengelolaan & usaha \\
penangkapan & ikan kurau & berbasis \\
konservasi & (KONSERV) & terhadap \\
perubahan kepentingan & terkait \\
kriteria pengelolaan dapat & dilihat \\
pada (Tabel 1).
\end{tabular}

Tabel 1 Hasil Analisis Sensitivitas Prioritas Strategi Pengelolaan Usaha Penangkapan Ikan Kurau Berbasis Konservasi (KONSERV) 


\begin{tabular}{|c|c|c|c|c|}
\hline \multirow{2}{*}{ No } & \multirow{2}{*}{$\begin{array}{c}\text { Kriteria } \\
\text { Pengelolaan } \\
\text { Usaha } \\
\text { Penangkapan } \\
\text { Ikan Kurau }\end{array}$} & \multirow{2}{*}{$\begin{array}{c}\text { Rasio } \\
\text { Kepentingan } \\
\text { (RK) Awal }\end{array}$} & \multicolumn{2}{|c|}{$\begin{array}{c}\text { Arahan Implementasi Prioritas } \\
\text { Strategi KONSERV }\end{array}$} \\
\hline & & & $\begin{array}{l}\text { Range RK } \\
\text { Stabil }\end{array}$ & $\begin{array}{l}\text { Range RK } \\
\text { Sensitif }\end{array}$ \\
\hline 1 & Biologi & 0,328 & $0-1$ & tidak ada \\
\hline 2 & Teknis & 0,245 & $0-<0,394$ & $0,394-1$ \\
\hline 3 & Sosial & 0,242 & $0-<0,421$ & $0,421-1$ \\
\hline 4 & Ekonomi & 0,184 & $0-<0,628$ & $0,628-1$ \\
\hline
\end{tabular}

Informasi yang detail tentang kondisi sumberdaya perikanan disertai opsi pengelolaannya, dapat meningkatkan efektifitas pengelolaan, karena upaya pengendaliannya telah disiapkan secara dini (Mumby et al ., 1999). Dimensi perubahan dalam pengelolaan perikanan dapat terjadi karena adanya intervensi dari orangorang yang berkepentingan terkait (stakeholders) dan dimensi perubahan alamiah pada alam.Dimensi perubahan ini dapat ditunjukkan oleh perubahan kepentingan dalam pemenuhan kriteria pengelolaan yang ada.Pada opsi kriteria strategi pengelolaan usaha penangkapan ikan kurau ini terdiri dari beberapa kriteria yaitu, kriteria biologi, teknis, sosial dan ekonomi. Setiap kriteria akan diuji sensitivtasnya terhadap opsi strategi terpilih (KONSERV) terhadap kriteria-kriteria yang ada.

Berdasarkan (Tabel 1) strategi pengelolaan usaha penangkapan ikan kurau berbasis KONSERV menunjukkan sensitif terhadap beberapa perubahan kepentingan untuk memenuhi kriteria, untuk kriteria biologi tidak memiliki nilai sensitivitas, karena tidak ada yang bisa melebihi nilainya, maka prioritas strategi pengelolaan usaha penangkapan ikan kurau tetap berbasis KONSERV. Strategi
KONSERV sangat tepat dalam pengelolaan usaha penangkapan ikan kurau berkelanjutan, mengingat ancaman yang tinggi terhadap biologis ikan kurau.

Kriteria teknis memiliki nilai sensitivitas (0,394-1), jika kriteria teknis menjadi perhatian maka prioritas strategi berubah menjadi penyuluhan dan pembinaan (PDP).Hal ini sangat mendukung bila kita ingin memprioritaskan kriteria teknis dalam pengelolaan usaha penangkapan ikan kurau maka strategi PDP yang diprioritaskan, karena strategi PDP memberikan pengetahuan dalam memilih dan menggunakan unit teknologi penangkapan ikan kurau yang berkelanjutan.Kriteria sosial memiliki nilai sensitivitas $(0,421-1)$ dan jika kriteria sosial menjadi perhatian maka prioritas strategi berubah juga menjadi penyuluhan dan pembinaan (PDP). Hal ini sangat mendukung bila kita ingin memprioritaskan kriteria sosial dalam pengelolaan usaha penangkapan ikan kurau maka strategi PDP yang diprioritaskan, karena sosialisasi PDP sangat penting dalam membangun kesadaran masyarakat untuk pengelolaan usaha penangkapan ikan kurau berkelanjutan.

Kriteria ekonomi memiliki nilai sensitivitas $(0,628-1)$, jika 
kriteria ekonomi menjadi perhatian maka prioritas strategi turut berubah menjadi Penyuluhan dan Pembinaan (PDP). Hal ini sangat mendukung bila kita ingin memprioritaskan kriteria ekonomi dalam pengelolaan usaha penangkapan ikan kurau maka strategi PDP yang diprioritaskan, karena PDP terhadap pemasaran dan harga pasar sangat penting perannya untuk ekonomi nelayan dan seharusnya pemerintah lebih menekankan kebijakan terkait hal itu. Penerapan implementasi strategi KONSERV sedikit sensitif dan cukup mudah terpengaruh oleh perubahan pencapaian kriteria pengelolaan yang diintervensi atau diinginkan oleh stakholders. Dengan demikian strategi KONSERV perlu pengawasan dan dukungan dari semua pihak, untuk mewujudkan pengelolaan usaha penangkapan ikan kurau yang berkelanjutan. Konsep pengembangan pengelolaan perikanan yang stabil dan mampu mengakomodir kondisi yang ada akan menjamin keberlanjutan dan penerimaan konsep tersebut di suatu kawasan (Simbolon dan Mustaruddin, 2006).

\section{KESIMPULAN}

Hasil dari penelitian ini dapat disimpulkan bahwa strategi pengelolaan usaha penangkapan ikan kurau lebih diarahkan ke strategi Konservasi (KONSERV)sebagai prioritas pertama dengan nilai sebesar (0,328), diikuti prioritas keduaBantuan Operasional (BOP) sebesar $(0,245)$, prioritas ketiga Penyuluan Dan Pembinaan(PDP) sebesar $(0,242)$ dan prioritas keempat Kredit Usaha Rakyat (KUR) sebesar $(0,184)$ dengan inconsistency terpercaya 0,04 .

\section{DAFTAR PUSTAKA}

Sensitivitas opsi kebijakan pengembangan perikanan tangkap terkait kriteria pengelolaan yang ada sangat dibutuhkan untuk memberi arahan bagi implementasinya di lokasi yang diamati.Hal ini memberikan kemudahan bagi pelaku usaha perikanan terutama nelayan kecil untuk efisiensi pembiayaan melaut (Malanesia, 2008).

Usaha penangkapan ikan kurau memiliki permasalahan yang kompleks dan cukup sulit diatasi, permasalahan yang biasa dihadapi nelayan di Indonesia yaitu:

1. Kapasitas SDM perikanan yang masih rendah

2. Tingginya permodalan dan investasi yang diperlukan dalam pengembangan Industri perikanan tangkap terutama untuk sumberdaya teknologi.

3. Layanan perbankan yang masih kurang mendukung (suku bunga bank yang tinggi dalam bidang perikanan, hampir mencapai 20\%) dan

4. Harga BBM yang tidak menentu (Astarini, 2011).

\section{UCAPAN TERIMA KASIH}

Penulis mengucapkan banyak terima kasih kepada Lembaga Pengelola Dana Pendidikan (LPDP) selaku lembaga yang telah membiayai penelitian ini dengan surat perjanjian kontrak LPDP Nomor:

PRJ-4379 /LPDP.3/2016.Selain itu penulis juga mengucapkan terima kasih kepada Fakultas Perikanan Universitas Muara Bungo yang telah mensponsori tahap editing hingga terbitnya tulisan ini. 
[DKP] Dinas Kelautan dan Perikanan. 2003. Data Statistik Perikanan dan Kelautan Kabupaten Bengkalis Provinsi Riau. Bengkalis.

[FAO] Food and Agricultural Organization. 1997. Fisheries Management. Technical Guidelines for Responsible Fisheries, Rome.

[PSDKP] Pengawas Sumberdaya Kelautan Perikanan. 2014. Surat Kepala Stasiun Pengawasan Sumber Daya Kelautan dan Perikanan (PSDKP) Belawan nomor: 03.19.03/Sta.2/SP.110/III/2014 tanggal 19 Maret 2014. Belawan (ID). $5 \mathrm{hlm}$.

Adrianto L. Pengelolaan Perikanan dengan Pendekatan Ekosistem (Integrasi Platform

Pengelolaan Kawasan

Konservasi Perairan dan Perikanan).(Bogor, PKSPLIPB. Bogor, 2015) hlm 6-32.

Astarini JE. Opini Terhadap Kebijakan Pemerintah dalam Pengembangan Industri Perikanan Tangkap. (Bogor, Pemanfaatan dan Pengelolaan Sumberdaya Perikanan Laut Berkelanjutan, New Paradigm in Marine Fisheries, Departemen PSP FPIK IPB, 2011) Hlm 23-35.

Dahuri R. Menuju Indonesia Sebagai Poros Maritim Dunia.(Bogor, Roda Bahari Press, 2016), 294 hlm.

Dahuri R. Paradigma Baru Pembangunan Indonesia Berbasis Kelautan. Orasi Ilmiah Guru Besar Tetap Bidang Pengelolaan Sumberdaya Pesisir dan Kelautan, (Bogor, Fakultas
Perikanan dan Ilmu Kelautan IPB, 2003), $233 \mathrm{hlm}$.

Indra. 2013. "Hubungan Kondisi Lingkungan Perairan Terhadap Produksi Ikan Kurau (Eleutheronema tetradactylum) Di Teluk Pambang Kabupaten Bengkalis". Program Pascasarjana Ilmu Lingkungan Universitas Riau. JOM UR, 1(1):165-175.

Isnaniah."Pengembangan Perikanan Tangkap Berbasis Sumberdaya Ikan Demersal di Perairan Kota Dumai Provinsi Riau".(Tesis, Institut Pertanian Bogor, 2009), $80 \mathrm{hlm}$.

Kesteven GL. Manual of Fisheries Science An Introduction to Fisheries Science. (Rome, FAO Fisheries Technical Paper, 1973), No.118. Rome $43 \mathrm{hlm}$.

Kinseng RA. Konflik Nelayan. (Jakarta, Yayasan Pustaka Obor Indonesia, 2014). 273 hlm.

Kusnandar, Mulyani S. 2015. "Strategi Pengelolaan Sumberdaya Perikanan Berbasis Ekosistem". OSEATEK, 9 (1): 9-20.

Malanesia M. 2008. "Sensititivitas Opsi Pengembangan Unit Penangkapan Ikan Terpilih di Kabupaten Lampung Selatan".Bul PSP. 17(1):88110.

Mumby PJ, Green EP, Edwards AJ, Clark CD. 1999. "The Costeffectiveness Of Remote Sensing For Tropical Coastal Resources Assessment And Management". Journal of Environmental Management, 55:157-166.

Mustaruddin 2011."Analisis

Kesesuaian Pengembangan 
Perikanan Pancing (Hook and Line) dengan Karakteristik Lingkungan dan Sosial di Perairan Teluk Tiworo, Sulawesi Tenggara".JTPK, 1(2):25-35.

Nasution A. "Analisis Ekologi Ikan Kurau (Eleutheronema tectradactylum) pada perairan laut Bengkalis Provinsi Riau". (Tesis: Universitas Indonesia, 2009), $69 \mathrm{hlm}$.

Nikijuluw.Rezim Pengelolaan

Sumberdaya Perikanan.

(Jakarta, Kerjasama P3R dan

Pustaka Cidesindo, 2002).254 hlm.

Nomura M, Yamazaki T. Fishing Techniques. (Tokyo, Japan International Cooperation Agency, 1975).206 pp.

Purnomo. Bustari, Huri E. (2013).

"Manajemen Operasi

Penangkapan Ikan dan

Kelayakan Ekonomi Gillnet (Jaring Kurau) Nelayan Desa Pambang Kabupaten Bengkalis”. JOM UR, 1(1):113.

Rengi P, Brown A, Studi Konservasi Ikan Kurau Di Selat Malaka Provinsi Riau. (Pekanbaru, Seminar Nasional Konservasi dan Proteksi Lingkungan, 2013). $27 \mathrm{hlm}$.

Rengi P, Tang UM, Syahza A, Ikhwan SY. 2015." Status, Exploration Potential and Resource Management of Kurau (Eleutheronema Tetradactylum) Fish In Overfishing Area (Case Study In Bengkalis District, Riau Province)". IJREES, 3(2):8-13.

Saaty TL. Pengambilan Keputusan. (Jakarta, PT Pustaka Binaman Pressindo. 1991), 270 hlm.
Sari TEY, Wisudo SH, Monintja DR, Purwaka T. 2009. "Prospek Pengembangan Perikanan Tangkap Di Perairan Provinsi Riau”. Bul PSP (18):133-141.

Satria A. Pengantar Sosiologi Masyarakat Pesisir. (Jakarta , Yayasan Pustaka Obor Indonesia, 2015) $149 \mathrm{hlm}$.

Simbolon D, Mustaruddin. 2006. "Prioritas Kebijakan Pengembangan Sistem Perikanan Cakalang di Perairan Sorong". Bul PSP, 15(2):7385.

Suraji. 2015. Konservasi Kunci Pengelolaan Perikanan Berkelanjutan: Mengukuhkan Pilar Keberlanjutan, Kedaulatan dan Kesejahteraan [Internet]. Bogor (ID): IPB. Hlm 1-24; [diunduh 2017 Maret 2017]. Tersedia pada: https://id.linkedin.com/pulse/k onservasi-kunci-pengelolaanperikanan-berkelanjutan-pilarsuraji.

Syaifuddin.Pendugaan Potensi dan Pola Musim Penangkapan Ikan Kurau (Eleutheronema tetradactylum) di Perairan Pulau Bengkalis. (Pekanbaru, Lembaga Penelitian Universitas Riau , 2008). 35 hlm.

Tahapary J, Simbolon D, Nurani TW. 2010. "Strategi Pengembangan Perikanan Pelagis Kecil di Perairan Kabupaten Maluku Tenggara”. Forum Pascasarjana, 33(4):285-297.

Zulbainarni N. Teori dan Praktik Pemodelan Bioekonomi dalam Pengelolaan Perikanan Tangkap.(Bogor, PT Penerbit IPB Press, 2012). 